\title{
Serpula and Spiraserpula (Polychaeta, Serpulidae) from the Tropical Western Atlantic and Gulf of Guinea
}

\author{
Rolando Bastida-Zavala, ${ }^{1, \dagger}$ \\ I Laboratorio de Sistemática de Invertebrados Marinos (LABSIM), Universidad del Mar, campus Puerto Án- \\ gel, Ciudad Universitaria, Apdo. Postal 47, Puerto Ángel, Oaxaca, 70902, México \\ † urn:lsid:zoobank.org:author:1512199F-C9A2-41FC-B474-786F512D38B7 \\ Corresponding author: Rolando Bastida-Zavala (rolando@angel.umar.mx)
}

Academic editor: Chris Glasby | Received 29 February 2012 | Accepted 15 May 2012 | Published 30 May 2012

urn:lsid:zoobank.org:pub:E560B1E4-2C12-45A9-B026-EE942C6EC240

Citation: Bastida-Zavala R (2012) Serpula and Spiraserpula (Polychaeta, Serpulidae) from the Tropical Western Atlantic and Gulf of Guinea. ZooKeys 198: 1-23. doi: 10.3897/zookeys.198.3030

\begin{abstract}
Six species of Serpula and Spiraserpula were identified, mainly, from the material of the expeditions of the Rosenstiel School of Marine and Atmospheric Science, University of Miami, including two new species of Serpula. Serpula madrigalae sp. n. from the Turks and Caicos has a tube with five longitudinal ridges, four rows of alveoli and a medium-sized shallow symmetrical opercular funnel with 17 radii, and an inner surface with opercular tubercles. Serpula vossae sp. $\mathbf{n}$. from the Western Caribbean and Bahamas has a tube with 6-8 longitudinal ridges, and a large, deep symmetrical opercular funnel, with 21-33 radii, and a smooth inner surface. Serpula cf. vermicularis, recorded from the Gulf of Guinea (tropical eastern Atlantic), is distinguished from the nominal species in possessing fewer opercular radii (33-39) and the lack of a proximal rasp in the bayonet chaetae; tubes are missing. The distribution range is extended for the three known Spiraserpula species found in the collections, S. caribensis, S. karpatensis and S. ypsilon.
\end{abstract}

\section{Resumen}

Seis especies de Serpula y Spiraserpula fueron identificadas, principalmente del material de las expediciones de la Rosenstiel School of Marine and Atmospheric Science, University of Miami, incluyendo dos nuevas especies de Serpula. Serpula madrigalae sp. n. es descrita de las Turks y Caicos, se caracteriza por tener un tubo con cinco costillas longitudinales, con cuatro hileras de alvéolos y un embudo simétrico, mediano y somero, con 17 radios, y la superficie opercular interna con tubérculos. Serpula

Copyright Rolando Bastida-Zavala. This is an open access article distributed under the terms of the Creative Commons Attribution License 3.0 (CC-BY), which permits unrestricted use, distribution, and reproduction in any medium, provided the original author and source are credited. 
vossae sp. n. es descrita del Caribe occidental y Bahamas; su tubo tiene 6-8 costillas longitudinales, un embudo opercular simétrico, largo y profundo, con 21-33 radios, y la superficie opercular interna lisa. Serpula cf. vermicularis es registrada del golfo de Guinea (Atlántico oriental tropical); se distingue de la especie nominal por tener menos radios operculares (33-39) y le falta la denticulación fina proximal en las setas bayoneta, los tubos se perdieron. Para las tres especies de Spiraserpula halladas, S. caribensis, $S$. karpatensis y $S$. ypsilon, se amplió el ámbito de distribución.

\section{Keywords}

Annelida, Bahamas, Caribbean, new records, new species, taxonomy, Turks and Caicos

\section{Introduction}

Serpula Linnaeus, 1758 the type genus of the polychaete family Serpulidae Rafinesque, 1815, has 31 species (ten Hove and Kupriyanova 2009, Pillai 2009). Six species have been described in the Eastern Atlantic and Mediterranean, including the type species, S. vermicularis Linnaeus, 1767, S. concharum Langerhans, 1880, S. lobiancoi Rioja, 1917, S. planorbis Southward, 1963, S. israelitica Amoureux, 1976 and S. cavernicola Fassari \& Mòllica, 1991. However, there are taxonomic problems in some species because they were poorly described and/or recorded from widely separated localities. For example, S. vermicularis has been recorded from several tropical, subtropical, temperate and cold water localities of the world (Kupriyanova 1999). There is a consensus now that $S$. vermicularis, previously considered to be a cosmopolitan species, is ill-defined and its distribution is possibly restricted to temperate and cold waters of the North Atlantic Ocean and Mediterranean (ten Hove and Jansen-Jacobs 1984, Imajima and ten Hove 1984, Kupriyanova and Jirkov 1997, Kupriyanova 1999, ten Hove and Kupriyanova 2009).

In the Western Atlantic, the genus Serpula is very poorly known, as only two species have been recorded: S. vermicularis granulosa by Day (1973) from Beaufort, North Carolina, and Serpula sp. A by ten Hove and Wolf (1984) from the northeastern Gulf of Mexico. Another taxon, S. sombreriana McIntosh, 1885, from Sombrero and St. Thomas Islands, lacks an operculum and was therefore transferred to Hyalopomatus (Ben-Eliahu and Fiege 1996).

The current state of our knowledge on Serpula species, compared to that of almost 100 species of Hydroides (ten Hove and Kupriyanova 2009, Pillai 2009), is probably explained by the fact that most tropical Serpula species are sublittoral and many extend their distribution into deeper waters. In cold and temperate waters, Serpula species can be present in shallow waters, attain larger sizes (Kupriyanova 1999), and form large aggregations, even reefs (Ramos and San Martin 1999).

Spiraserpula Regenhardt, 1961 was established initially for fossil serpulids. Pillai and ten Hove (1994) revised the Recent species belonging to the genus. They described 16 species out of 19 currently included in the genus, and eight of them were from the Caribbean. The main distinguishing feature of this genus is their complex internal tube 
structures (ITS), described by Pillai and ten Hove (1994). Unfortunately, the species remain mostly unknown to non-specialists, mainly because they are tiny, most are sublittoral, and often overlooked or confused with other taxa.

This work is part of a larger study examining subtidal and deep sea serpulids from the Grand Caribbean region and from the Gulf of Guinea, tropical eastern Atlantic.

\section{Materials and methods}

Between 1963 and 1975, the Rosenstiel School of Marine and Atmospheric Science (RSMAS) conducted the University of Miami Deep Sea Expeditions aboard of R/V Gerda, John Elliot Pillsbury, James M. Gillis and Columbus Iselin, and sampled more than 3,350 stations from the Gulf of Panama, throughout the Caribbean to the Gulf of Guinea, the Straits of Florida, the Bahamas, the area northward to the Bermudas and the deep basins and the deep waters, from the intertidal to $8,650 \mathrm{~m}$ in the Puerto Rico Trench (Voss et al. 1977, Bastida-Zavala et al. 2001). The revision of the serpulid material from these expeditions resulted in finding of 11 Serpula and 10 Spiraserpula specimens from the western Caribbean, Bahamas, Turks and Caicos, Los Roques Islands, Trinidad and Tobago, and in the Gulf of Guinea.

Additionally, two specimens of Serpula (recorded by Bastida-Zavala and SalazarVallejo 2000) and 14 specimens of Spiraserpula of the collections of El Colegio de la Frontera Sur and the Instituto de Oceanología of Cuba were available for study. Type specimens were deposited in the National Museum of Natural History, Smithsonian Institution, Washington, D.C. Other specimens were deposited in the collections of the respective lending institutions.

The specimens of Serpula and Spiraserpula were fixed with 10\% formalin and preserved with $70 \%$ alcohol. They were studied in a standardized way (ten Hove and Jansen-Jacobs 1984, Bastida-Zavala and ten Hove 2002). Line drawings were made using a camera lucida, and the photographs were taken with a digital camera Canon G11 fitted to a microscope adapter.

The main standard measurements and observations on Serpula were: total length (measured from most distal part of the operculum to the pygidium), thoracic width (measured from the collar region level), number of thoracic chaetigers, number of radioles in each lobe of the branchial crown, number of longitudinal ridges on the tube (not counting basal ridges attached to the substratum), presence or absence of peristomes, transverse ridges or alveoli on the tube, opercular length (measured from the base of funnel, or constriction, if present, to the tips of the radii), opercular diameter (measured across the distal part of the funnel), number of funnel radii, number of teeth on bayonet chaetae and the presence or absence of a proximal rasp in these chaetae. An exploratory analysis of the number of opercular radii and body length ratio of the Serpula species is included. Scales of figures and photographs are in millimeters. 
The following abbreviations are used in the text:

\section{Collections}

ECOSUR Colección de Referencia. El Colegio de la Frontera Sur, Chetumal, Quintana Roo, México.

UMML Marine Invertebrate Museum, Rosenstiel School of Marine and Atmospheric Science, University of Miami, Miami, Florida, USA.

UMAR Colección de Invertebrados Marinos, Universidad del Mar, Puerto Ángel, Oaxaca, México.

USNM National Museum of Natural History, Washington D.C., USA.

\section{Characters}

OL Opercular length

OD Opercular diameter

THW Thoracic width

TL Total length of the body

\section{Statistical terms}

$\begin{array}{ll}\text { n } & \text { sample size } \\ r: & \text { range of data } \\ \mu & \text { mean } \\ \pm & \text { standard deviation }\end{array}$

\section{Systematics}

Class Polychaeta Grube, 1850

Family Serpulidae Rafinesque, 1815

Genus Serpula Linnaeus, 1758

Type species. Serpula vermicularis Linnaeus, 1767 by subsequent designation (Heppell 1963) under the plenary powers of the International Commission on Zoological Nomenclature (Evans and China 1966). 


\section{Serpula madrigalae sp. $\mathbf{n}$.}

urn:Isid:zoobank.org:act:1EACCEA3-111D-4F4A-AF5B-CD03E15FBF6C http://species-id.net/wiki/Serpula_madrigalae

Figs $1 \mathrm{~A}-\mathrm{D}, 2 \mathrm{~A}-\mathrm{G}, 5,6$

Type locality. Turks and Caicos. East of Caicos Island.

Type material. Turks and Caicos. Holotype (USNM 1157006), RV Pillsbury, cruise 7106 , sta. $1423,21^{\circ} 41^{\prime} \mathrm{N}, 71^{\circ} 23^{\prime} \mathrm{W}, 10$-feet otter trawl, $18 \mathrm{~m}$, July 19, 1971 (ex UMML 22.1054).

Description. Tube color greenish yellow (Fig. 2A-B); with five longitudinal ridges, lateral-most ridges larger than middle ones (Figs 1C-D, 2A-B); lacking transverse ridges and peristomes; with four rows of alveoli, more evident between dorsal-most longitudinal ridges (Figs 1C, 2A-B).

Body yellowish-brown, branchial crown and operculum yellow pale (preserved material only, Fig. 2C). TL= $20 \mathrm{~mm}$; THW= $1.6 \mathrm{~mm}$. Branchial crown with 18 radioles in each lobe; lacking branchial membrane.

Peduncle smooth, with well-defined constriction (Fig. 2D); inserted in left lobe. Club-shaped pseudoperculum present.

Operculum with moderately long, shallow, symmetrical funnel; lacking bulbous basal part (Figs 1A, 2D-E). OL= $2.3 \mathrm{~mm}, \mathrm{OD}=1.4 \mathrm{~mm}$. Interradial grooves $1 / 3$ of funnel length (Figs 1A, 2E). Funnel has 17 radii with rounded tips. Opercular inner surface with irregular tubercles (Figs 1B, 2D).

Collar thick, with short ventral and dorsal lobes. Thorax consists of seven chaetigers. Collar chaetal fascicles symmetrical with regard to size and composition, unlike in some specimens of $S$. vossae sp. n. Bayonet chaetae with two blunt-elongate teeth, distal blade smooth, lacking proximal rasp (Figs 2F); hooded (capillary) chaetae present (Fig. 2G).

Thoracic membranes well developed, narrowing toward to last thoracic chaetigers, fused ventrally, forming a short apron. Remaining six thoracic chaetigers with hooded (limbate) chaetae of two sizes; saw-shaped uncini.

Anterior part of abdomen lacking distinct achaetous region. Anterior and middle abdominal chaetigers with flat-trumpet chaetae. Posterior chaetigers with 'capillary' chaetae. Anterior and posterior uncini saw-shaped.

Etymology. Named after my wife, Dr Socorro García-Madrigal, a specialist on crustaceans, who gave me the necessary encouragement and time to undertake this research.

Distribution. Only recorded from the vicinity of Caicos Island, Turks and Caicos Islands (Fig. 6).

Ecology. Sublittoral, $18 \mathrm{~m}$. In the same sample there were other serpulids: Pomatostegus stellatus, Pseudovermilia multispinosa, Spirobranchus giganteus, and Vermiliopsis annulituba.

Remarks. Serpula madrigalae sp. n. resembles other Serpula species with symmetrical, moderately long and shallow funnels, such as $S$. cavernicola, S. granulosa Marenzeller, 1884, S. israelitica Amoureux, 1976, S. jukesii Baird, 1865, S. narconensis Baird, 1865, S. oshimae Imajima \& ten Hove, 1984, S. tetratropia Imajima \& ten Hove, 


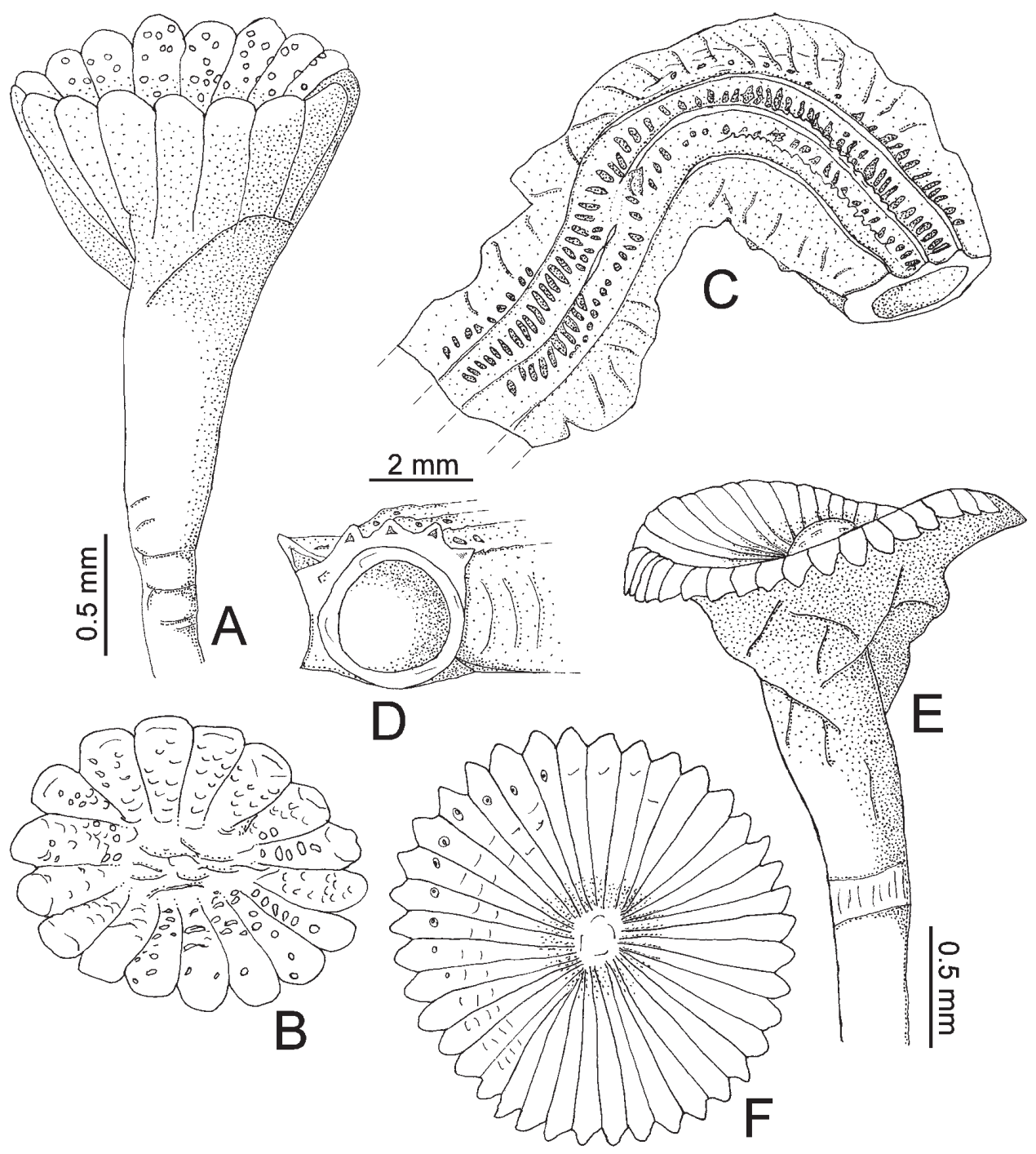

Figure I. A-D Serpula madrigalae sp. n., from Turks and Caicos Islands, USNM 1157006, holotype A-B operculum in lateral and aboral views $\mathbf{C}-\mathbf{D}$ tube in dorsal and frontal views E-F Serpula cf. vermicularis, from Nigeria, UMML 22.545 E-F operculum in lateral and aboral views.

1984, S. vermicularis Linnaeus, 1767, and S. zelandica Baird, 1865. However, S. madrigalae sp. n. differs from all other Serpula species with regard to its characteristic tube which has five longitudinal ridges and four rows of alveoli (Figs 1C-D, 2A-B).

Serpula madrigalae sp. n. resembles $S$. vermicularis granulosa, in having tubercles on the internal surface of the operculum; however, the diagnosis of the latter species 


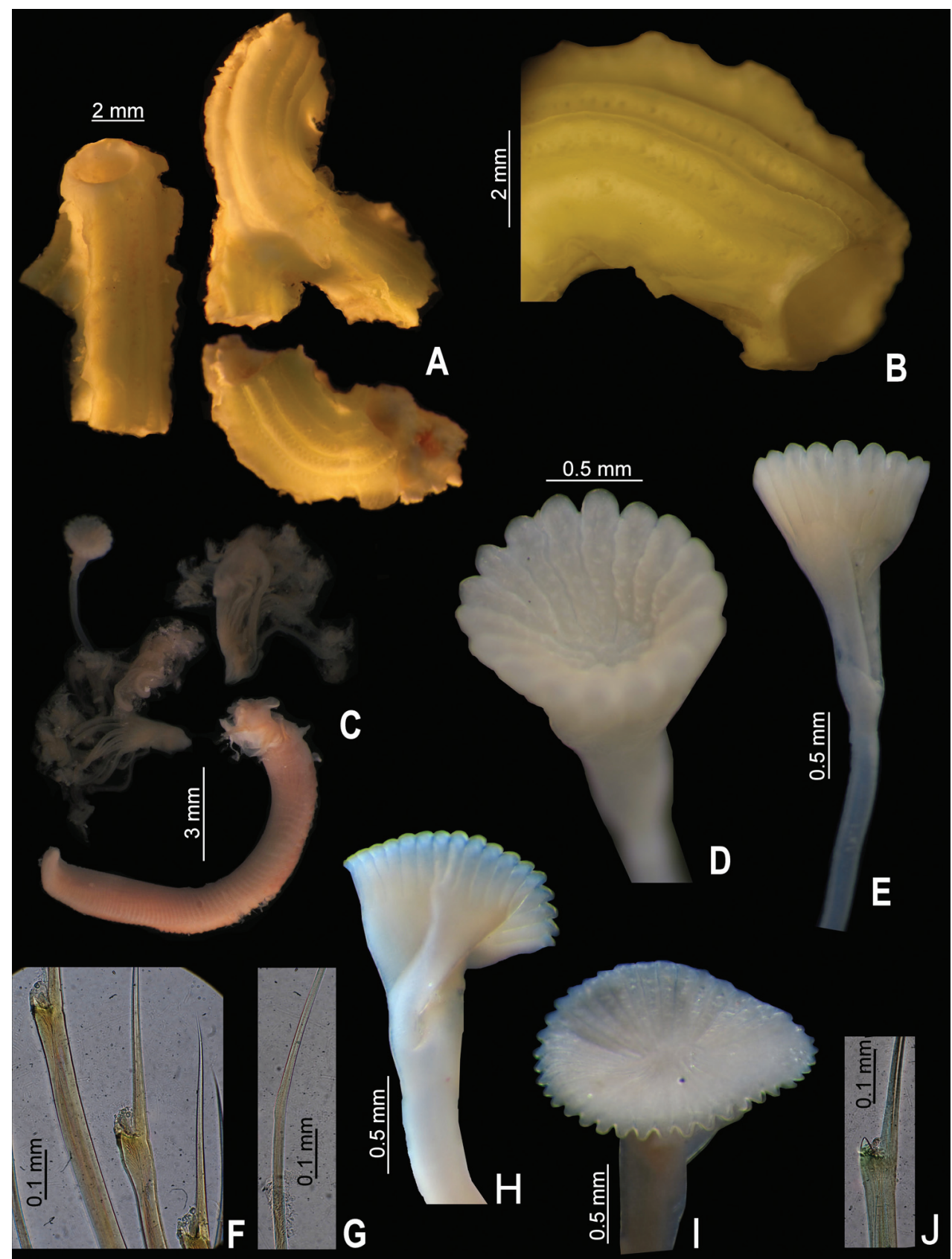

Figure 2. A-G Serpula madrigalae sp. n., from Turks and Caicos, USNM 1157006, holotype A-B tube and detail $\mathbf{C}$ entire body $\mathbf{D}-\mathbf{E}$ operculum, in aboral and lateral views $\mathbf{F}$ bayonet chaetae $\mathbf{G}$ hooded (capillary) chaetae H-J Serpula cf. vermicularis, from Nigeria, UMML 22.545 H-I two distinct opercula in lateral and aboral views $\mathbf{J}$ bayonet chaetae. 
was brief (Day 1973). At least S. madrigalae sp. n. differs by the tube with five longitudinal ridges and four rows of alveoli (Figs $1 \mathrm{C}-\mathrm{D}, 2 \mathrm{~A}-\mathrm{B}$ ), while $S$. vermicularis granulosa is "faintly ridged" (Day 1973:131); also, Day (1973) mentioned more opercular radii (20-40) than present in Serpula madrigalae sp. n. (17, Figs 1B, 5).

Serpula madrigalae sp. n. also resembles Serpula sp. A, from the northeastern part of the Gulf of Mexico, with regard to the shape of the operculum, the number of radii and the depths from which they were collected. However, they differ with regards to other features: S. madrigalae sp. n. has irregular tubercles on the internal surface of the operculum (Figs 1B, 2D) and lacks a proximal rasp in the bayonet chaetae (Fig. 2F), while Serpula sp. A lacks tubercles (ten Hove and Wolf 1984, Fig. 55-8a) and has bayonet chaetae with a proximal rasp. Additionally, ten Hove and Wolf (1984) mentioned that all the specimens lacked their tubes. Hence is not possible to assign the specimens recorded as Serpula sp. A. to S. madrigalae sp. n.

\section{Serpula vossae sp. $\mathrm{n}$.}

urn:lsid:zoobank.org:act:3165E4EF-A4B8-47B2-B500-D5C8C1557646 http://species-id.net/wiki/Serpula_vossae

Figs 3A-D, 4A-J, 5, 6

Serpula sp. Bastida-Zavala and Salazar-Vallejo, 2000:852-854, fig. 4B-K.

Type locality. Honduras. Southwest of Honduras.

Type material. Holotype (USNM 1157004), RV Pillsbury, cruise 6802, sta. 629, $15^{\circ} 58^{\prime} \mathrm{N}, 86^{\circ} 09^{\prime} \mathrm{W}, 40 \mathrm{~m}$, March 21, 1968 (ex UMML 22.611); paratype (USNM 1157005), RV Pillsbury, cruise 6802, sta. 628, Honduras, East of Cayos Cochinos, $15^{\circ} 57^{\prime} \mathrm{N}, 86^{\circ} 15^{\prime} \mathrm{W}, 47 \mathrm{~m}$, March 21, 1968 (ex UMML 22.610).

Additional material. Guatemala. One complete specimen (UMML 22.1053) RV Pillsbury, cruise 6802, sta. 613, West of Punta Cortes, $15^{\circ} 58^{\prime} \mathrm{N}, 88^{\circ} 20^{\prime} \mathrm{W}, 10$-feet otter trawl, 39 m, March 19, 1968. México. One complete specimen (ECOSUR s.n.) RV Edwin Link sta. 2792, $13 \mathrm{~km}$ from East of Isla Mujeres, Quintana Roo, $21^{\circ} 14^{\prime} \mathrm{N}$, $86^{\circ} 36^{\prime} \mathrm{W}, 130 \mathrm{~m}$, August 28, 1990, E. Escobar and L. Soto leg. Cuba. One complete specimen (Instituto de Oceanología de Cuba) Cayo Diego Pérez, Golfo de Batabanó, 15 m, July 20, 1988, D. Ibarzábal leg. Bahamas. Two complete specimens (UMML 22.435) RV Gerda, cruise 6433, sta. 391, North of Bahamas, $27^{\circ} 20^{\prime} \mathrm{N}, 79^{\circ} 11^{\prime} \mathrm{W}$, screen dredge, $68 \mathrm{~m}$, September 19, 1964.

Description. Tube color brownish, or light brown to white; with 6-8 longitudinal ridges, all similar in size; some tubes with shallow transverse ridges, forming a rugged surface, other tubes lacking transverse ridges; most tubes lacking peristomes, two have only one peristome with appearance of a groove with shallow growth lines. Tubes lacking alveoli (Fig. 4A, C-D).

Body pale yellow (preserved material only, Fig. 4B). TL=38.5 mm ( $\mathrm{n}=7, \mathrm{r}: 20$ 45.5, $\mu=36.6 \pm 10.3)$; THW $=2 \mathrm{~mm}(\mathrm{n}=7, \mathrm{r}: 1.5-3.4, \mu=2.3 \pm 0.6)$. Branchial crown 

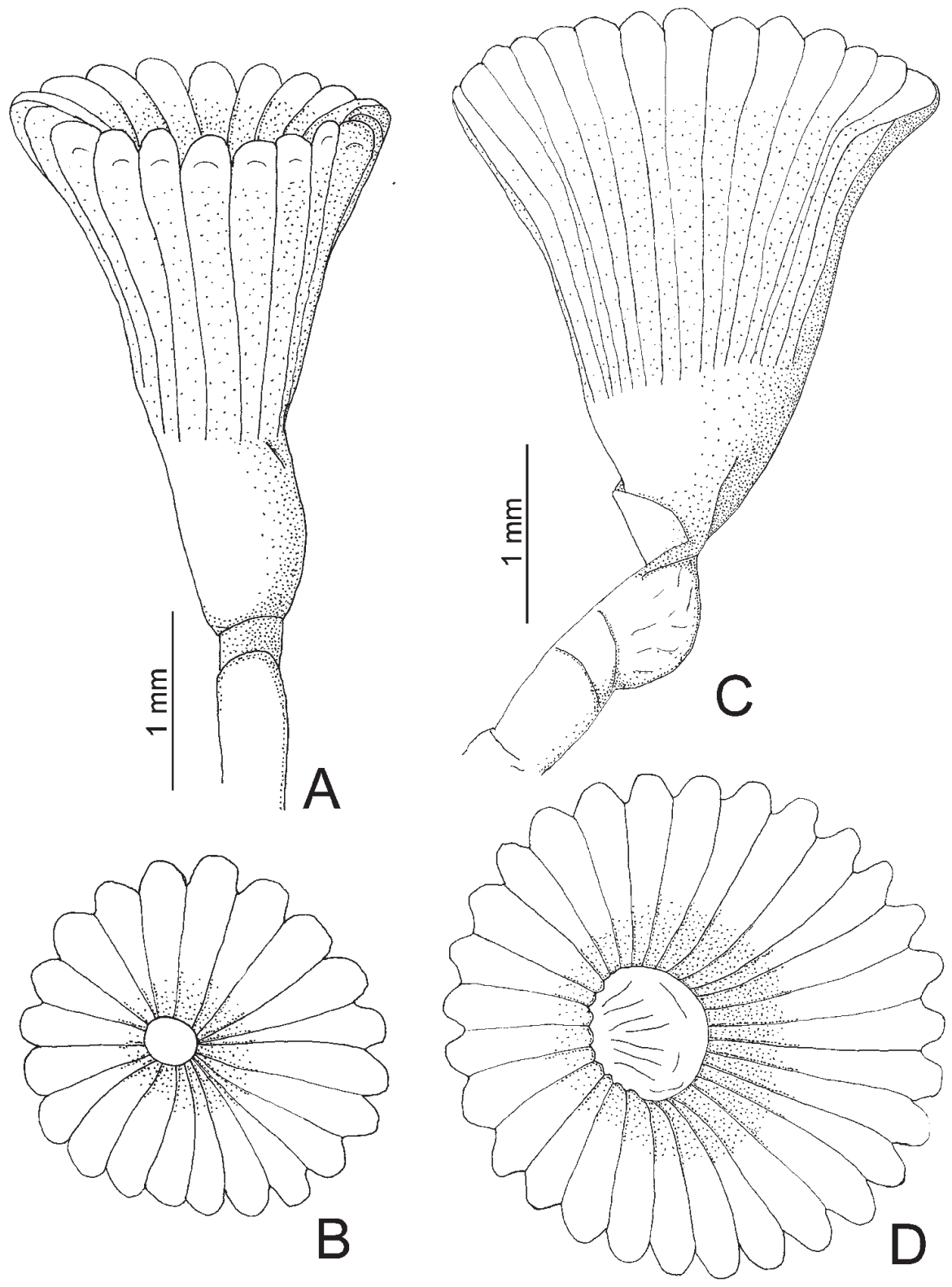

Figure 3. A-D Serpula vossae sp. n., from Honduras, USNM 1157004, holotype A-B operculum in lateral and aboral views; from Bahamas, UMML 22.435 C-D operculum in lateral and aboral views.

with 29 radioles $(\mathrm{n}=7, \mathrm{r}: 19-37, \mu=30.9 \pm 6.4)$ left, and 29 right $(\mathrm{n}=7, \mathrm{r}: 12-35, \mu=30.9$ \pm 8.8 ); lacking branchial membrane (Fig. 4E).

Peduncle smooth with insertion on left $(n=2)$ or right $(n=5)$; with shallow $(n=4)$ to well-defined constriction ( $\mathrm{n}=3$ ) (Figs 3A, C, 4H-J). Pseudoperculum club-shaped, present in all specimens. 


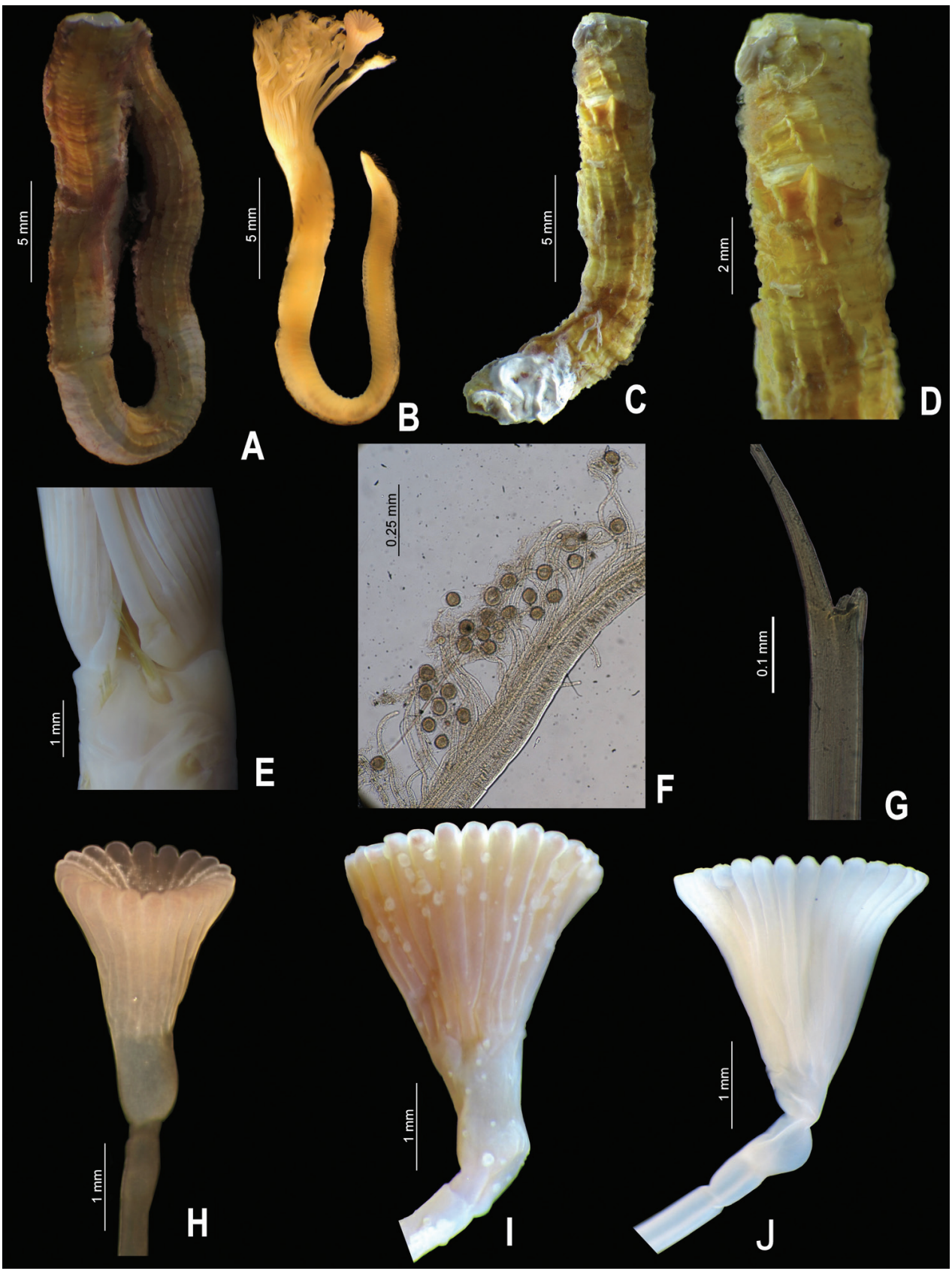

Figure 4.A-J Serpula vossae sp. n., from Honduras, USNM 1157004, holotype A tube B entire body; from Guatemala, UMML 22.1053 C-D tube and detail of peristome; from Bahamas, UMML 22.435 E collar region; from Cuba, IO F radiole with eggs; from Honduras, USNM 1157004, holotype G bayonet chaetae $\mathbf{H}$ operculum; from Guatemala, UMML 22.1053 I operculum; from Bahamas, UMML $22.435 \mathrm{~J}$ operculum. 
Operculum with long, deep symmetrical funnel; with a slightly bulbous basal part above constriction (Figs 3A, C, 4H-J). OL=3.2 $\mathrm{mm}(\mathrm{n}=7, \mathrm{r}: 2-4.5, \mu=3.3 \pm 0.8), \mathrm{OD}=$ $2 \mathrm{~mm}(\mathrm{n}=7, \mathrm{r}: 1.4-2.8, \mu=2.3 \pm 0.5)$. Interradial grooves $2 / 3$ of funnel length. Funnel with 21 radii $(n=7, r: 21-33, \mu=27.4 \pm 3.7)$ with rounded tips (Figs 3A, C, 4H-J). Opercular inner surface lacking tubercles (Fig. 3A-D).

Collar thick, with short ventral and dorsal lobes. Thorax consists of seven chaetigers. Collar fascicles in three specimens asymmetrical with regard to sizes and number of chaetae; right fascicle with larger and more chaetae than left fascicle (Fig. 4E). Bayonet chaetae with two blunt-elongate teeth, distal blade smooth, lacking proximal rasp (Fig. 4G); hooded (capillary) chaetae present.

Thoracic membranes well developed, narrowing toward last thoracic chaetigers, fused ventrally, forming a short apron. Remaining six thoracic chaetigers with hooded (limbate) chaetae of two sizes; saw-shaped uncini.

Anterior part of abdomen lacks a distinct achaetous region. Anterior and middle abdominal chaetigers with flat-trumpet chaetae. Posterior chaetigers with 'capillary' chaetae. Anterior and posterior uncini saw-shaped.

Variation. Operculum of holotype (USNM 1157004) has roseate radial tips (Fig. 4H); the rest of specimens are yellow to white (Fig. 4I-J). Operculum and radioles of specimen from Guatemala (UMML 22.1053) have hard particles adhered, possibly salt concretions (Fig. 4I); operculum more rigid compared with the other specimens.

Etymology. Named after Professor Nancy Voss, a distinguished cephalopod specialist and Director of the Marine Invertebrate Museum, who generously loaned the serpulid samples from the oceanographic expeditions of the University of Miami.

Distribution. Tropical Caribbean. Bahamas, Cuba, Mexican Caribbean, Guatemala and Honduran Caribbean (Fig. 6).

Ecology. Sublittoral, 15 to $130 \mathrm{~m}$. On rocky and sandy bottoms, and associated with siliceous sponges and several syllid polychaetes specimens. In the same samples, there were other serpulids: Hyalopomatus sp., Hydroides parvus, Pomatostegus stellatus, Pseudovermilia fuscostriata, P. occidentalis, Spiraserpula ypsilon, and a vermetid shell.

Reproductive characters. The specimen from Cayo Diego Pérez, Cuba, has eggs adhering to the pinnules of the radioles. The eggs, circular to slightly oval, are 55-68 $\mu \mathrm{m}$ (Fig. 4F).

Remarks. Serpula vossae sp. n. resembles other Serpula species with long and deep symmetrical funnels, as in S. columbiana Johnson, 1901, S. concharum Langerhans, 1880, S. longituba Imajima, 1979, S. sinica Wu \& Chen, 1979, S. uschakovi Kupriyanova, 1999, S. vittata Augener, 1914, and S. watsoni Willey, 1905. However, $S$. vossae sp. n. differs in having an operculum with a smooth inner surface, while S. watsoni has tubercles (Pillai 2009); S. vossae sp. n. has fewer opercular radii (21-33, Figs 4B-D, 5) than S. columbiana (55-160) or S. uschakovi (62-136) (Kupriyanova 1999); S. vossae sp. n. has 6-8 longitudinal ridges in the tube (Fig. 4A, C-D), while S. columbiana, S. longituba and S. uschakovi lack longitudinal ridges 


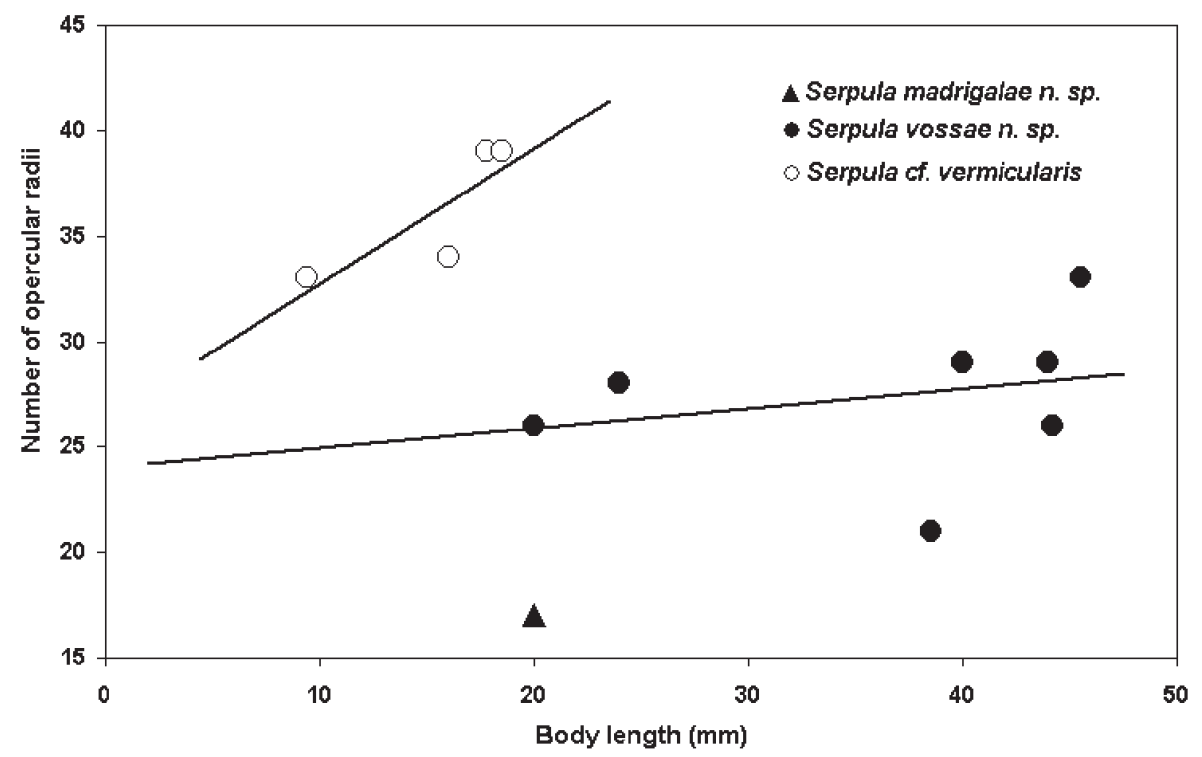

Figure 5. Exploratory analysis of the number of opercular radii and body length ratio: Serpula madrigalae sp. n. ( $\mathrm{n}=1$, only for reference), S. vossae sp. $\mathrm{n} .(\mathrm{n}=7)$, and $S$. cf. vermicularis $(\mathrm{n}=4)$.
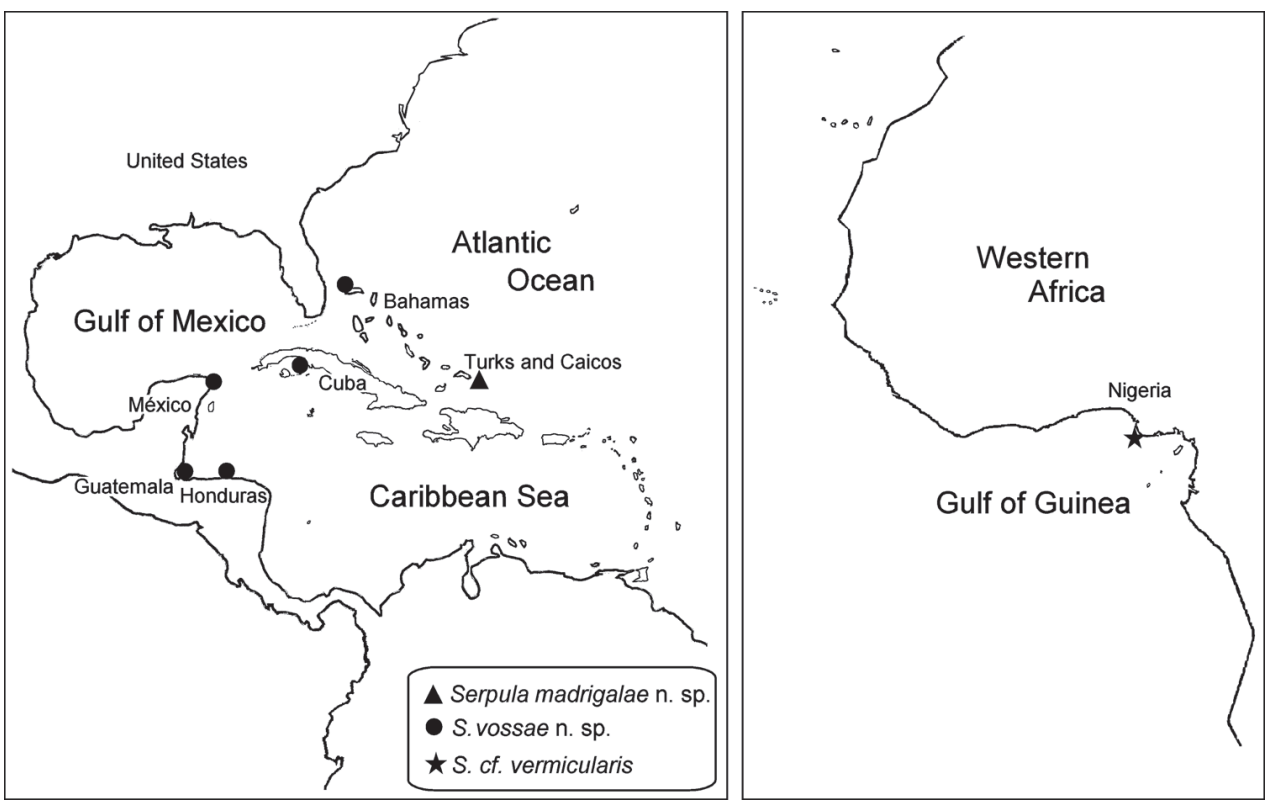

Figure 6. Distribution of Serpula madrigalae sp. n., Serpula vossae sp. n., and Serpula cf. vermicularis.

(Imajima 1979, Kupriyanova 1999), whereas S. concharum, S. vittata, and S. watsoni have five or less (Rioja 1931, Imajima 1977, 1982); S. vossae sp. n. has more radioles per branchial lobe (19-37) than S. concharum (6-15), S. longituba (9-10), 
S. sinica (13), while $S$. uschakovi has even more (43-61) than S. vossae sp. n. Serpula vossae sp. n. has collar chaetae with two teeth (Fig. 4G), while S. longituba lacks bayonet chaetae (Imajima 1979), S. sinica has bayonet chaetae lacking basal teeth (Wu et al. 1979), and S. vittata and S. watsoni have 10 and five basal teeth in the bayonet chaetae, respectively (Imajima 1977, 1982). These characters and others have been compared in Table 1.

Regarding the Serpula species recorded in the Western Atlantic, S. vossae sp. n. differs from S. vermicularis granulosa Day, 1973, from Beaufort, North Carolina, because the former has a longer, deeper operculum, and lacks tubercles on the internal funnel surface (Figs 3A-D, 4H-J); while S. vossae sp. n. differs from Serpula sp. A (ten Hove and Wolf 1984) and S. madrigalae sp. n. because the former has a longer and deeper operculum, with more opercular radii (21-33) than the latter (Serpula sp. A has 18 radii, $S$. madrigalae sp. n. has 17$)$.

Serpula vossae sp. n. differs from S. cf. vermicularis, recorded here from Nigeria, in the same characters mentioned for $S$. vermicularis granulosa, and, additionally in having fewer opercular radii in relation to the body length than the latter (Fig. 5).

\section{Serpula cf. vermicularis}

Figs 1E-F, 2H-J, 5, 6

Material examined. Nigeria. Five specimens (UMML 22.545), RV Pillsbury, sta. 248, Southeast of Lagos, $4^{\circ} 05^{\prime} \mathrm{N}, 5^{\circ} 40$ 'E, 10-foot try-net, 33 m, May 13, 1965.

Description. Tubes missing. Body light brown (preserved material only). $\mathrm{TL}=$ $18.5 \mathrm{~mm}(\mathrm{n}=4, \mathrm{r}: 9.4-18.5, \mu=36.6 \pm 10.3)$; THW $=1.7 \mathrm{~mm}(\mathrm{n}=5, \mathrm{r}: 1.2-1.7, \mu=1.6$ \pm 0.2 ). Thoracic membranes and opercular peduncles of all the specimens damaged. Branchial crown with 27 radioles $(\mathrm{n}=4, \mathrm{r}: 19-27, \mu=23.8 \pm 3.4)$ left, and 25 right $(\mathrm{n}=4$, r: $17-25, \mu=22.5 \pm 3.7)$; lacking inter-radiolar membrane.

Peduncle smooth, with insertion on left $(\mathrm{n}=2)$ or right $(\mathrm{n}=2)$; lacking constriction between it and operculum, its position represented only by a slight change in color (Figs 1E, 2I). Club-shaped pseudoperculum present in all specimens.

Operculum with short, shallow symmetrical funnel; lacking bulbous basal part (Figs 1E, 2I). $\mathrm{OL}=2 \mathrm{~mm}(\mathrm{n}=4, \mathrm{r}: 1.3-2.1, \mu=1.9 \pm 0.4), \mathrm{OD}=1.8 \mathrm{~mm}(\mathrm{n}=4, \mathrm{r}: 1.1-1.8$, $\mu=1.6 \pm 0.3$ ). Interradial grooves $1 / 4$ of funnel length (Fig. $2 \mathrm{H}$ ). Funnel with up to 39 radii $(n=4, r: 33-39, \mu=36.3 \pm 3.2)$ with blunt tips (Fig. 1E-F). Opercular inner surface lacking tubercles (Figs 1E-F, 2I).

Collar thick, with ventral and dorsal lobes short. Thorax consists of seven chaetigers. Collar chaetal fascicles symmetrical with regard to size and composition unlike in S. vossae sp. n. Bayonet chaetae with two blunt-elongate teeth, distal blade smooth, lacking proximal rasp (Fig. 2J); hooded (capillary) chaetae present.

Thoracic membranes apparently well developed (membranes damaged), narrowing toward posterior thorax, fused ventrally, forming a short apron. Remaining six thoracic chaetigers with hooded (limbate) chaetae of two sizes; saw-shaped uncini. 


\begin{tabular}{|c|c|c|c|c|c|c|c|c|c|c|c|c|}
\hline $\begin{array}{l}\text { S } \\
\text { cs } \\
\text { s. }\end{array}$ & 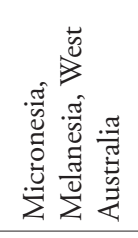 & 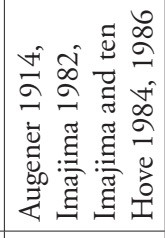 & $=$ & 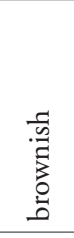 & $n$ & 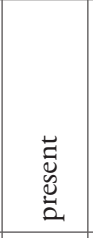 & 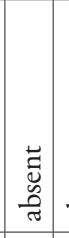 & 莺 & $\because$ & $\begin{array}{l}\widetilde{A} \\
\infty \\
\infty\end{array}$ & 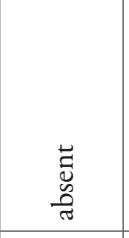 & \\
\hline 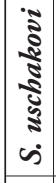 & 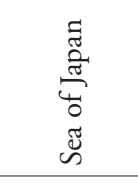 & $\begin{array}{l}\text { 袁 } \\
\text { 言 }\end{array}$ & $\cong$ & $\frac{\mathscr{g}}{\bar{z}}$ & n. & n. & . & .. & $=$ & 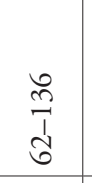 & 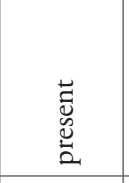 & \\
\hline 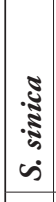 & 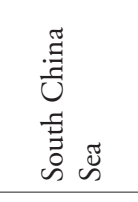 & 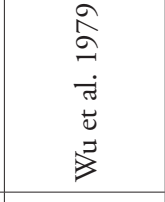 & 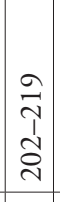 & 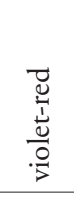 & n. & n. & .. & $\therefore=$ & n. & $\tilde{n}$ & & \\
\hline 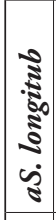 & 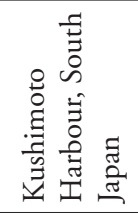 & 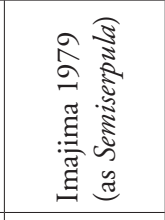 & $\mid \begin{array}{c}0 \\
0 \\
0 \\
m\end{array}$ & $\frac{\mathscr{g}}{3}$ & 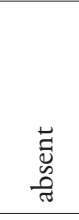 & 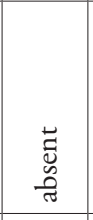 & 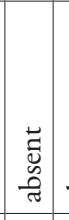 & 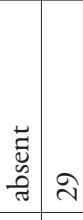 & $\begin{array}{l}\infty \\
0 \\
0\end{array}$ & $\approx$ & 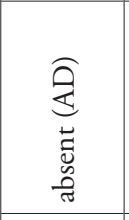 & \\
\hline 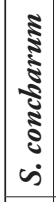 & 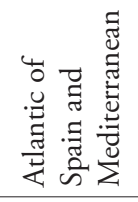 & 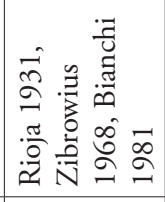 & $\mid \begin{array}{l}8 \\
h \\
0 \\
0\end{array}$ & $\frac{\mathscr{E}}{\bar{B}}$ & 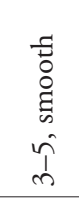 & 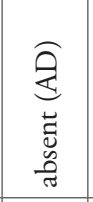 & 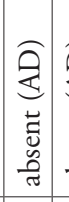 & 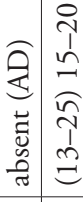 & $\stackrel{n}{2}$ & $\begin{array}{l}\text { â } \\
\underline{n} \\
\end{array}$ & & \\
\hline 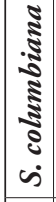 & 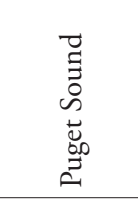 & 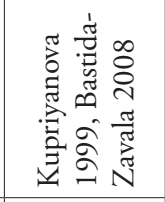 & $\begin{array}{c}8 \\
0 \\
1 \\
\end{array}$ & $\frac{\mathscr{E}}{3}$ & 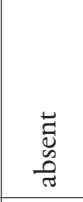 & 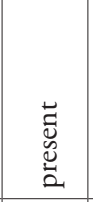 & . & 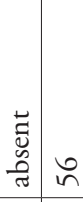 & 6 & $\begin{array}{l}0 \\
\vdots \\
1 \\
n\end{array}$ & 莺 & \\
\hline 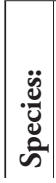 & 莺 & 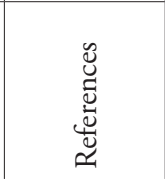 & $|\stackrel{0}{ }|$ & $\begin{array}{l}\stackrel{\overrightarrow{0}}{0} \\
\overline{0} \\
\stackrel{0}{\vec{F}}\end{array}$ & 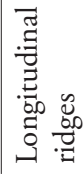 & 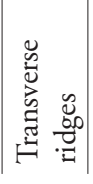 & & 咅 & $\mid \begin{array}{c}\text { 量 } \\
\text { 年 }\end{array}$ & 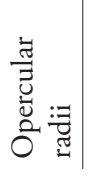 & 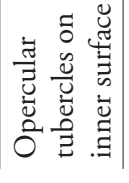 & \\
\hline
\end{tabular}


Serpula and Spiraserpula (Polychaeta, Serpulidae) from the Tropical Western Atlantic...

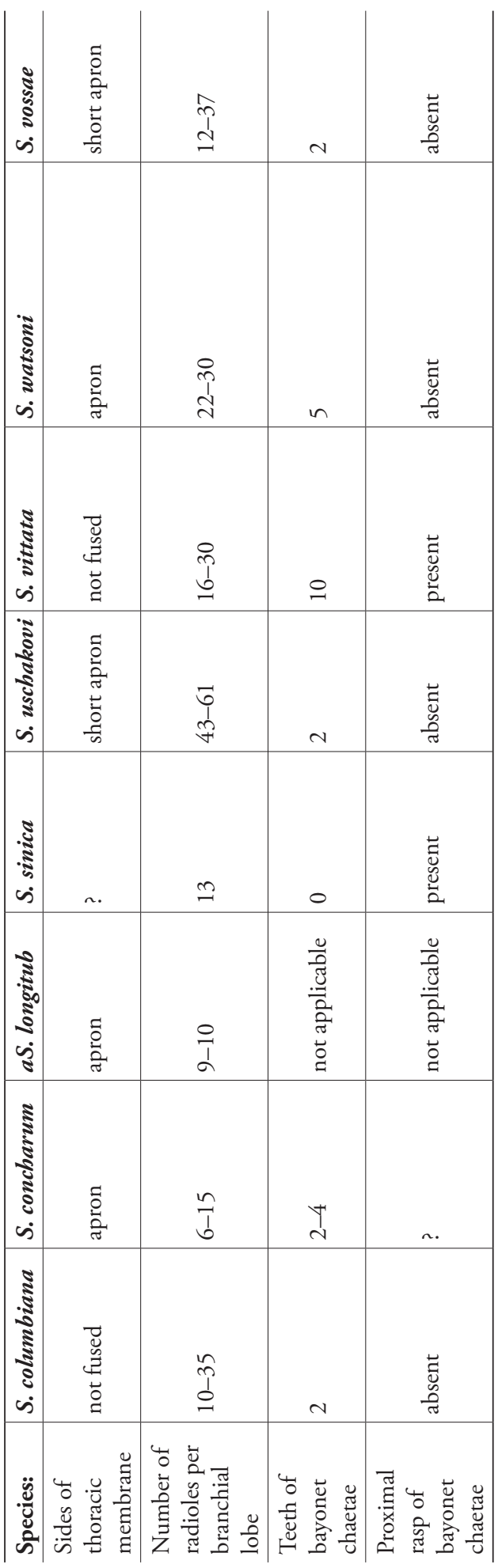


Abdomen with anterior achaetous region. Anterior and middle abdominal chaetigers with flat-trumpet chaetae. Posterior chaetigers with 'capillary' chaetae. Anterior and posterior uncini saw-shaped.

Variation. Two specimens with a hyaline circle in radii tip (Fig. 1F). One specimen with few inconspicuous tubercles in interior funnel surface.

Distribution. Nigeria, Gulf of Guinea (Fig. 6).

Ecology. Sublittoral, $33 \mathrm{~m}$.

Remarks. Serpula cf. vermicularis resembles the nominal species; unfortunately, the tubes of all the specimens are missing. There are some differences with the nominal species, particularly with regard to the number of radii: Serpula cf. vermicularis has 33-39 opercular radii (Fig. 1F, 2I, 5), while Zibrowius (1968) recorded specimens from Marseille with more than 40 opercular radii, and Kupriyanova and Jirkov (1997) recorded specimens from Norway and Iceland with a mean of 50.8 opercular radii; and the proximal rasp of the bayonet chaetae: Serpula cf. vermicularis lacks a proximal rasp (Fig. 2J), while Rioja (1931) and Kupriyanova (1999, Table 1) mentioned that their specimens have a proximal rasp.

Zibrowius (1973) recorded several specimens as S. vermicularis, from Western Africa (from Angola to Morocco); unfortunately the description was too brief and did not included figures; however, Zibrowius (1973) mentioned that the specimens that he reviewed showed considerable variation.

\section{Genus Spiraserpula Regenhardt, 1961}

Type species. Spiraserpula spiraserpula Regenhardt, 1961 (fossil), by original designation.

\section{Spiraserpula caribensis Pillai \& ten Hove, 1994}

http://species-id.net/wiki/Spiraserpula_caribensis

Figs $7 \mathrm{~A}-\mathrm{D}, 8$

Spiraserpula caribensis Pillai \& ten Hove 1994:68-76, Figs 3L, 14A-M, 15A-Y, 16AK, Pls. 4E-F, 5A-E.

Type locality. Awa Blancu, Curaçao.

Material examined. Panama Caribbean. One specimen (ECOSUR P0615) Colon, Club Náutico, fouling prospection, June 3, 2002, S.I. Salazar-Vallejo leg. Mexican Caribbean. Nine specimens (ECOSUR P0614, P0616), two specimens (UMML 22.1061), two specimens (UMAR-Poly 110), Playa Azul, Cozumel, coral rock, 10 m, March 25, 2001, leg. H.A. ten Hove.

Description. Some specimens forming tube aggregations; others were found isolated. Tubes sinuous or spiraled (Fig. 7A), with two internal ridges: mid-dorsal one 


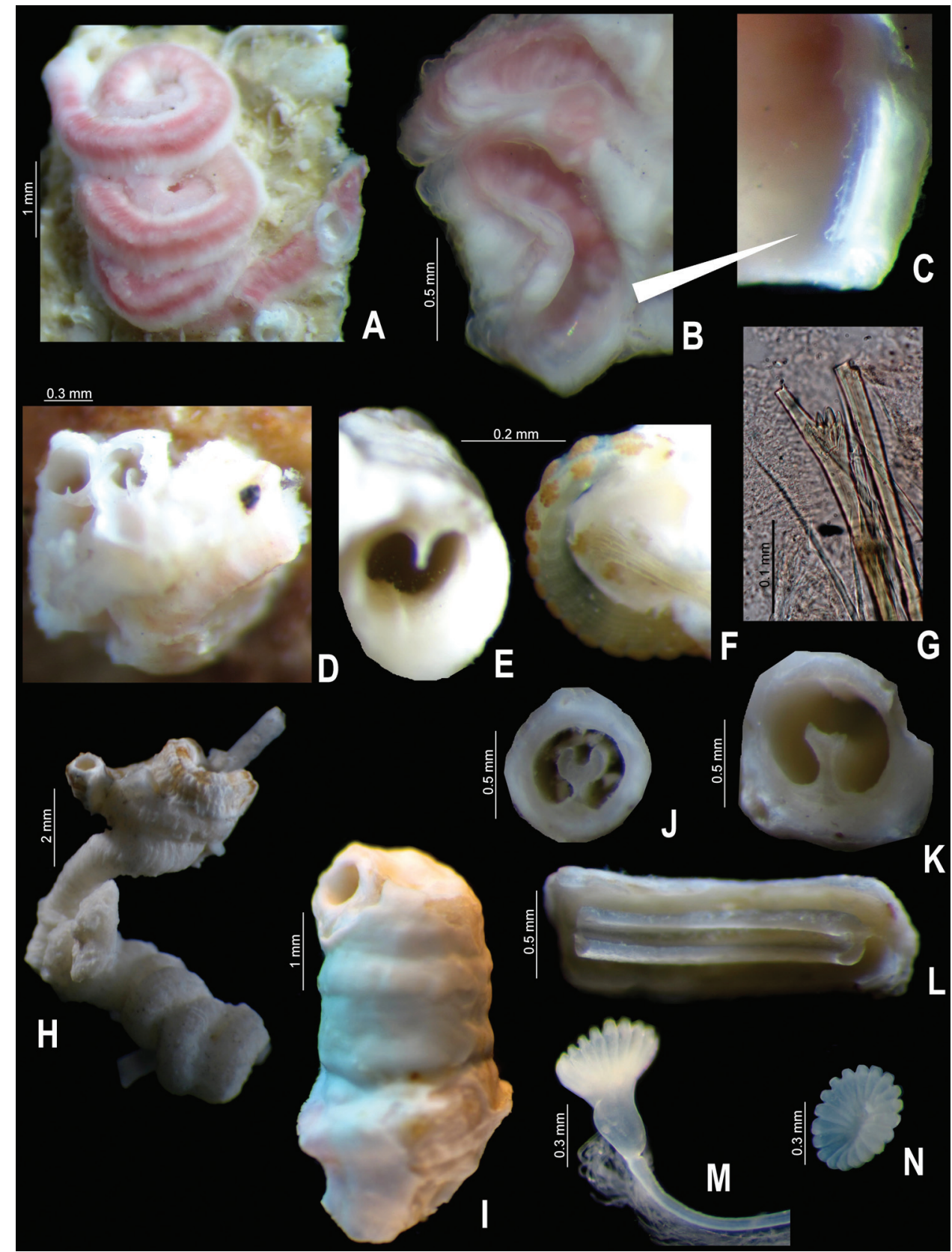

Figure 7. A-D: Spiraserpula caribensis, from Cozumel, UMAR-Poly 110 A complete tube B-C internal surface of the tube and detail of ventral internal ridge $\mathbf{D}$ other specimen with lateral internal ridges E-F S. karpatensis, from Los Roques Islands, UMML 22.1055 E detail of the mouth tube $\mathbf{F}$ abdomen with gametes G-L S. ypsilon, from Trinidad and Tobago, UMML 22.1059 G collar chaetae; from Bahamas, UMML 22.1056 $\mathbf{H}$ tube attached to Pseudovermilia fuscostriata; from Trinidad and Tobago, UMML 22.1059 I tube; from Honduras, UMML 22.1057 J-K tube in cross section $\mathbf{L}$ tube in longitudinal section M-N Spiraserpula sp., from Los Roques Islands, UMML 22.1060 M-N operculum, lateral and aboral views. 

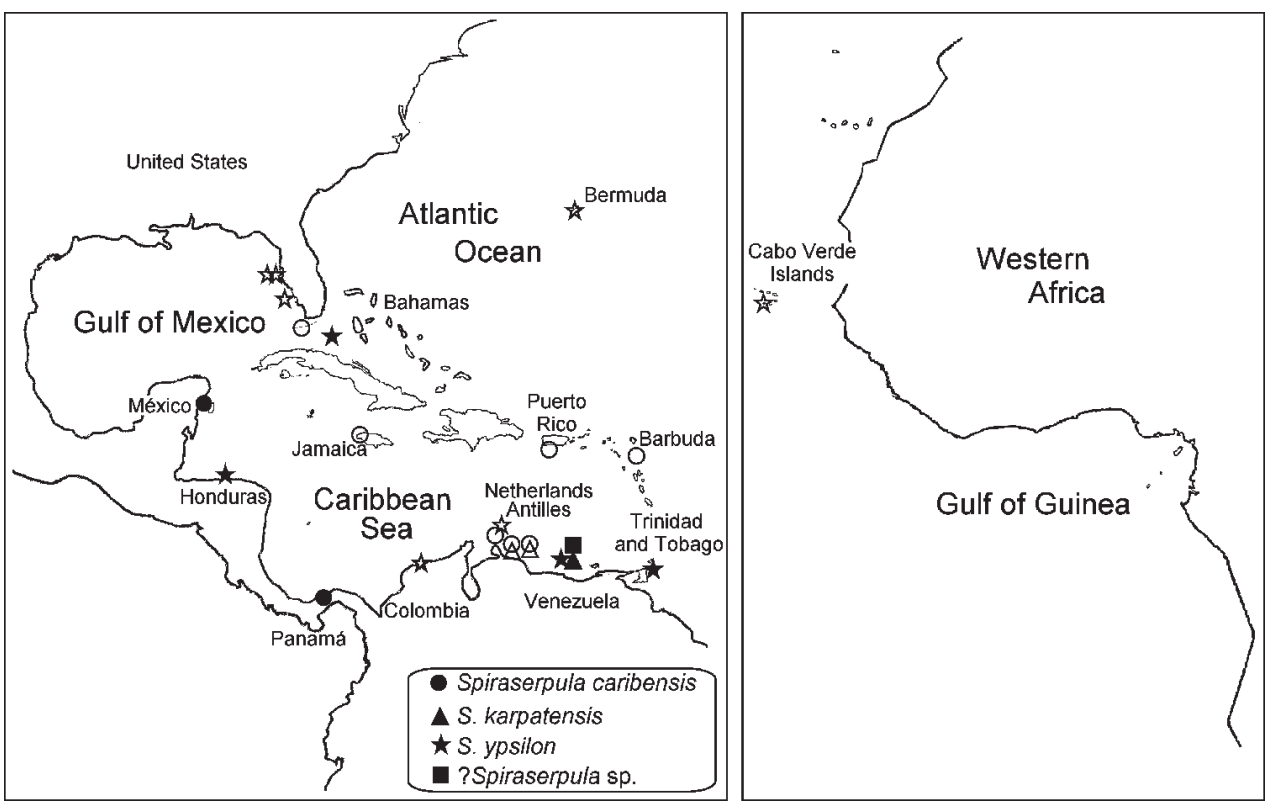

Figure 8. Distribution of Spiraserpula caribensis, S. karpatensis, S. ypsilon and ?Spiraserpula sp. Closed symbols denote examined material, open symbols literature records.

smooth, mid-ventral one serrated (Fig. 7B-C), occasionally with two internal lateral ridges (Fig. 7D). Some tubes externally pinkish, others with two dorsal pink bands (Fig. 7A-B). Body brown to dark brown (preserved material only). The worms are damaged. Branchial crowns lost. Thorax with eight chaetigers, including collar fascicles. Abdomen damaged.

Distribution. Caribbean, Florida and Pacific of Panama.

Ecology. Intertidal to sublittoral, $10 \mathrm{~m}$. On coral debris. Pillai and ten Hove (1994) recorded the species from 0-18 m deep.

Remarks. Spiraserpula caribensis is easily distinguishable from the other Caribbean species by their pink tubes (Fig. 7A).

\section{Spiraserpula karpatensis Pillai \& ten Hove, 1994}

http://species-id.net/wiki/Spiraserpula_karpatensis

Figs $7 \mathrm{E}-\mathrm{F}, 8$

Spiraserpula karpatensis Pillai \& ten Hove 1994:64-65, Figs 3N, 11A-K.

Type locality. Karpata, Bonaire.

Material examined. Venezuela. One incomplete specimen and one empty tube (UMML 22.1055), RV Pillsbury, cruise 6806, sta. 745, North of Los Roques Islands, $11^{\circ} 58^{\prime} \mathrm{N}, 66^{\circ} 50^{\prime} \mathrm{W}, 10$-feet otter trawl, $65 \mathrm{~m}$, July 24, 1968. 
Description. Empty tube larger (Fig. 7E) than occupied one attached to empty tubes of $S$. ypsilon. Tubes sinuous or spiraled, with two internal ridges: mid-dorsal one smooth, mid-ventral one serrated (Fig. 7E). Both tubes white, internal and externally (Fig. 7E). The branchial crown and thorax of incomplete specimen is missing. Abdomen partially transparent, with double packets of gametes in each segment (Fig. 7F).

Distribution. Eastern Caribbean. Bonaire, Curaçao and Los Roques Islands.

Ecology. Sublittoral, 65 m. On coral debris. Pillai and ten Hove (1994) recorded the species from depths of 10-30 m. The sample also contained two Spiraserpula species: S. ypsilon and Spiraserpula sp., a chaetopterid tube, a lumbrinerid and several empty tubes of serpulids resembling Protula and Vermiliopsis.

Remarks. Spiraserpula karpatensis resembles $S$. caribensis with regard to the dorsal and ventral ridges (Fig. 7C, E); however, S. karpatensis does not possess pinkish tubes unlike $S$. caribensis.

\section{Spiraserpula ypsilon Pillai \& ten Hove, 1994}

http://species-id.net/wiki/Spiraserpula_ypsilon

Figs $7 \mathrm{G}-\mathrm{L}, 8$

Spiraserpula ypsilon Pillai \& ten Hove 1994:56-60, Figs 6A-K, 7A-T, 34G, Pl. 1 B.

Type locality. Brava, Cape Verde Islands.

Material examined. Bahamas. Two empty tubes (UMML 22.1056), RV Gerda, cruise 6804, sta. 983, North of Elbow Cay, Bahamas, $24^{\circ} 05^{\prime} \mathrm{N}, 80^{\circ} 20^{\prime} \mathrm{W}$, triangle dredge, 216 m, March 5, 1968). Honduras. One specimen (UMML 22.1057), RV Pillsbury, cruise 6802, sta. 629, Southwest of Honduras Cape, $15^{\circ} 58^{\prime} \mathrm{N}$, $86^{\circ} 09^{\prime} \mathrm{W}, 41$-feet otter trawl, $40 \mathrm{~m}$, March 21, 1968. Venezuela. Two empty tubes (UMML 22.1058), RV Pillsbury, cruise 6806, sta. 745, North of Los Roques Islands, $11^{\circ} 58^{\prime} \mathrm{N}, 66^{\circ} 50^{\prime} \mathrm{W}, 10$-feet otter trawl, $65 \mathrm{~m}$, July 24, 1968. Trinidad and Tobago. One specimen (UMML 22.1059), one specimen (UMAR-Poly 111), RV Pillsbury, cruise 6907 , sta. 840 , East of Trinidad Island, $10^{\circ} 40^{\prime} \mathrm{N}, 60^{\circ} 37^{\prime} \mathrm{W}, 10$-feet otter trawl, $33 \mathrm{~m}$, sponges, July 1, 1969.

Description. One specimen (UMML 22.1058) attached to tube of $S$. karpatensis and another (UMML 22.1056) attached to Pseudovermilia fuscostriata tube (Fig. 7H). Tubes sinuous or strongly spiraled (Fig. $7 \mathrm{H})$; in another the tube forms a very tight cylindrical spiral (Fig. 7I). Tubes with two internal longitudinal ridges: mid-dorsal one serrated, mid-ventral one Y-shaped (Fig. 7J-L); sometimes, along length of tube, Y-shaped ridge changes to smooth ridge. Tubes white (Fig. 7H-I). Body pale to dark brown (preserved material only). Worms damaged. Branchial crown with 5-6 radioles by branchial lobe. Collar damaged, lobes could not be observed. Bayonet chaetae with 3-4 blunt teeth (Fig. 7G); hooded (capillary) chaetae present. Thorax with seven chaetigers, including collar chaetae. Abdomen damaged.

Distribution. Caribbean, Florida and Pacific of Panama. 
Ecology. Sublittoral, 33-216 m. On coral debris. Pillai and ten Hove (1994) recorded the species from 0.5 to $200 \mathrm{~m}$. In the same samples studied there were other serpulids: Spiraserpula karpatensis, Spiraserpula sp., Hydroides gairacensis, Hydroides sp. 1, Pomatostegus stellatus, Protula sp., Pseudovermilia fuscostriata, P. occidentalis, Salmacina huxleyi, S. vossae sp. n., Vermiliopsis annulata, a chaetopterid tube, and other polychaetes: a lumbrinerid, several syllids, sipunculids and a vermetid shell.

Remarks. Spiraserpula ypsilon is very similar to $S$. paraypsilon Pillai \& ten Hove, 1994, described from the Netherlands Antilles, mainly with regard to the internal ridges of the tube. However, some differences separate both species, mainly the absence of lateral tubercles in the thoracic uncini in S. ypsilon, characteristic of S. paraypsilon; additionally, S. ypsilon has fewer radioles (6-7) than S. paraypsilon (11).

\section{?Spiraserpula sp.}

Figs $7 \mathrm{M}-\mathrm{N}, 8$

Material examined. Venezuela. One specimen (UMML 22.1060), RV Pillsbury, cruise 6806, sta. 745 , North of Los Roques Islands, $11^{\circ} 58^{\prime} \mathrm{N}, 66^{\circ} 50^{\prime} \mathrm{W}, 10$-feet otter trawl, 65 m, July 24, 1968.

Description. Tube attached to a chaetopterid tube, is white and lacks any internal ridges characteristic of Spiraserpula. External surface with granular appearance, internally smooth. Body white, fragmented and damaged but complete. Branchial crown with nine radioles per lobe; lacking inter-radiolar membrane.

Peduncle smooth, inserted in right lobe, with well-defined constriction between it and operculum (Figs 7M). Pseudoperculum club-shaped. Operculum is zygomorphic; with a conspicuous bulbous basal part above constriction (Fig. $7 \mathrm{M}$ ). Interradial grooves 1/3 of funnel length; 19 radii with rounded tips (Fig. 7N); inner surface smooth (Fig. 7N).

Collar damaged, lobes could not be observed. Bayonet chaetae with 2-3 sharpelongate teeth; hooded (capillary) chaetae present. Thorax with eight chaetigers, including collar chaetae. Abdomen damaged, with approximately 61 segments, a distinct achaetous region absent between the thorax and abdomen.

Distribution. Only recorded from Los Roques Islands, Venezuela.

Ecology. Sublittoral, $65 \mathrm{~m}$. The same sample contained other serpulids: Spiraserpula karpatensis, S. ypsilon, several empty tubes of serpulids resembling Protula and Vermiliopsis, a chaetopterid tube, and a lumbrinerid.

Remarks. Most of the tube belonging to this specimen is missing and the remaining fragments lacked the internal ridges characteristic of Spiraserpula. The operculum of this Spiraserpula sp. resembles that of $S$. karpatensis, S. plaiae Pillai \& ten Hove, 1994 and S. sumbensis Pillai \& ten Hove, 1994; the former two are from Caribbean and the latter is from Indonesia. Due to the loss of the rest of the tube the present specimen cannot be assigned to species. It may be a juvenile stage of another genus, such as Crucigera or Serpula. 


\section{Discussion}

Despite having reviewed 158 lots of serpulids from the same number of stations collected during past deep sea expeditions, specimens of Serpula were found only at six stations $(3.8 \%)$, which combined with the fact that there were only two previous records of Serpula (Day 1973, ten Hove and Wolf 1984) from the U.S. Atlantic, indicates that the genus is very rare in the Western Atlantic.

However, the original descriptions of the species mentioned in the remarks, indicate that many are incomplete, unclear or contradictory with respect to the figures provided. Descriptions need to be standardized and include as many characters as possible, as argued extensively by ten Hove and Jansen-Jacobs (1984), Kupriyanova (1999), and ten Hove and Kupriyanova (2009).

As regards Spiraserpula, another little-known serpulid genus in the Caribbean closely similar to Serpula, complete descriptions of species were made in an important and recent revision of the genus, including most species from the Caribbean (Pillai and ten Hove 1994). Unfortunately, due to the characteristics of the internal tube structures and small size of the specimens, their manipulation and study of Spiraserpula is more difficult as compared to other serpulids.

\section{Acknowledgements}

The serpulid collections of the oceanographic expeditions of the Rosenstiel School of Marine and Atmospheric Science, University of Miami were made available by Nancy Voss (UMML-RSMAS, Miami) and the specimen from Cuba was loaned by Diana Ibarzábal (IO-Cuba). Generous accommodation and laboratory space were made available by Sergio Salazar-Vallejo and Emilia González (ECOSUR, Chetumal) besides their time, to study these interesting serpulids. Harry ten Hove (NCB Naturalis, Leiden) and Luis Carrera-Parra (ECOSUR, Chetumal) provided some critically important papers. Nancy Voss and Sergio Salazar-Vallejo made corrections and comments to an earlier draft. Two anonymous referees and Chris Glasby (as editor) made careful corrections and comments to the latest version. This work was partially supported by the project PROMEP/103-5/09/1353.

\section{References}

Augener H (1914) Polychaeta. II. Sedentaria. Michaelsen, W. \& Hartmeyer, R. Die fauna Südwest-Australiens, 5(1): 1-170.

Bastida-Zavala JR (2008) Serpulids (Annelida: Polychaeta) from the Eastern Pacific, including a brief mention of Hawaiian serpulids. Zootaxa 1722: 1-61. http://www.mapress.com/ zootaxa/2008/f/z01722p061f.pdf 
Bastida-Zavala JR, ten Hove HA (2002) Revision of Hydroides Gunnerus, 1768 (Polychaeta: Serpulidae) from the Western Atlantic Region. Beaufortia 52: 103-178.

Bastida-Zavala JR, Salazar-Vallejo SI (2000) Serpúlidos (Polychaeta: Serpulidae) del Caribe noroccidental: Hydroides y Serpula. Revista de Biología Tropical 48(4): 841-858. http:// www.scielo.sa.cr/scielo.php?pid=S0034-77442000000400009\&script=sci_arttext\&tlng=e

Bastida-Zavala JR, Carrera-Parra LF, Delgado-Blas VH, Londoño-Mesa MH, Salazar-Silva P, Salazar-Vallejo SI (2001) Polychaetes (Polychaeta) from the Gulf of Guinea, the Grand Caribbean Sea, and the Gulf of Panama deposited in the Museum of Marine Invertebrates, University of Miami. Final Report, ECOSUR, México, 60 pp. http://w2.ecosur-qroo.mx/ Bentos/wbentos/Documentos/polychaetes-Miami.doc

Ben-Eliahu MN, Fiege D (1996) Serpulid tube-worms (Annelida: Polychaeta) of the Central and Eastern Mediterranean with particular attention to the Levant Basin. Senckenbergiana Maritima 28(1-3): 1-51. doi: 10.1007/BF03042821

Bianchi CN (1981) Policheti Serpuloidei. Guideper il riconoscimento delle specie animali delle acque lagunari e costiere italiane, $\mathrm{AQ} / 1 / 96$, Consiglio Nazionale delle Ricerche, Genova 5: $1-187$.

Day JH (1973) New Polychaeta from Beaufort with a key to all species recorded from North Carolina. NOAA Technical Report, Seattle, 140 pp.

Evans GO, China WE (1966) Serpula Linnaeus, 1758 (Annelida, Polychaeta): designation of a type-species under the plenary powers. Bulletin of Zoological Nomenclature 23(1): 29-30. Heppell D (1963) Serpula Linnaeus, 1758 (Annelida, Polychaeta): proposed designation of a type-species under the plenary powers and relevant proposals. Z.N.(S.) 1606. Bulletin of Zoological Nomenclature 20(6): 443-446.

Hove HA ten, Jansen-Jacobs MJ (1984) A revision of the genus Crucigera (Polychaeta; Serpulidae); a proposed methodical approach of serpulids, with special reference to variation in Serpula and Hydroides. In: Hutchings PA (Ed.) Proceedings of the First International Polychaete Conference, The Linnean Society of New South Wales, Sydney, 143-180.

Hove HA ten, Kupriyanova EK (2009) Taxonomy of Serpulidae (Annelida, Polychaeta): The state of affairs. Zootaxa 2036: 1-126. doi: 10.3853/j.0067-1975.61.2009.1489

Hove HA ten, Wolf PS (1984) Family Serpulidae Johnston, 1865. In: Uebelacker JM, Johnson PG (Eds), Taxonomic guide to the polychaetes of the northern Gulf of Mexico, Barry A. Vittor, Mobile, Vol 7, 55.1-55.34

Imajima M (1977) Serpulidae (Annelida, Polychaeta) collected around Chichi-jima (Ogasawara Islands). Memories of the National Science Museum, Tokyo 10: 89-111.

Imajima M (1979) Serpulidae (Annelida, Polychaeta) collected around Cape Shionomisaki, Kii Peninsula. Memories of the National Science Museum, Tokyo 12: 159-183.

Imajima M (1982) Serpulinae (Polychaetous Annelids) from the Palau and Yap Islands, Micronesia. Proceedings of the Japanese Society Systematic Zoology 23: 37-55.

Imajima M, ten Hove HA (1984) Serpulinae (Annelida, Polychaeta) from the Truk Islands, Ponape and Majuro Atoll, with some other new Indo-Pacific records. Proceedings of the Japanese Society Systematic Zoology 27: 35-66. 
Imajima M, ten Hove HA (1986) Serpulinae (Annelida, Polychaeta) from Nauru, the Gilbert Islands (Kiribati) and the Solomon Islands. Proceedings of the Japanese Society Systematic Zoology 32: 1-16.

Kupriyanova EK (1999) The taxonomic status of Serpula cf. columbiana Johnson, 1901 from the American and Asian coasts of the North Pacific Ocean (Polychaeta: Serpulidae). Ophelia 50(1): 21-34. doi: 10.1080/00785326.1999.10409386

Kupriyanova EK, Jirkov IA (1997) Serpulidae (Annelida, Polychaeta) of the Arctic Ocean. Sarsia 82: 203-236.

Pillai TG (2009) Description of new serpulid polychaetes from the Kimberleys of Australia and discussion of Australian and Indo-West Pacific species of Spirobranchus and superficially similar taxa. Records of the Australian Museum 61(2): 93-199. doi: 10.3853/j.00671975.61.2009.1489

Pillai TG, ten Hove HA (1994) On recent species of Spiraserpula Regenhardt, 1961, a serpulid polychaete genus hitherto known only from Cretaceous and Tertiary fossils. Bulletin of the Natural History Museum, London, Zoology Series 60(1): 39-104.

Ramos A, San Martín G (1999) On the finding of a mass occurrence of Serpula narconensis Baird, 1885 (Polychaeta, Serpulidae) in South Georgia (Antarctica). Polar Biology 22: 379-383. doi: $10.1007 / \mathrm{s} 003000050432$

Rioja E (1931) Estudio de los poliquetos de la Península Ibérica. Memorias de la Academia de Ciencias Exactas y Físicas., Naturales, Madrid, 2: 1-471.

Voss GL, Robins CR, Staiger JC (1977) Study of the macro-fauna of the Tropical Western Atlantic. In: FAO Symposium of the Program of the Maritime Research of the Caribbean and Adjacent Regions, Caracas, FAO, Rome, 483-503.

Willey A (1905) Report on the Polychaeta collected by Professor Herdman, at Ceylon, in 1902. In Herdman, W.A. Report to the government of Ceylon on the pearl oyster fisheries of the Gulf of Manaar. London, Royal Society, 4, Supplement Report 30: 243-324.

Wu BL, Sun R, Chen M (1979) Two new species of the Polychaeta from the South China Sea. Oceanic Selections 2(2): 89-94.

Zibrowius H (1968) Étude morphologique, systematique et écologique, des Serpulidae (Annelida Polychaeta) de la région de Marseille. Recueil des travaux de la Station Marine d'Endoume, Bulletin 43(59): 81-253.

Zibrowius H (1973) Serpulidae (Annelida Polychaeta) des côtes Ouest de l'Afrique et des archipels voisins. Annales Musee Royal de l'Afrique Centrale, Belgique, series 8, Sciences Zoologiques (208): 1-93. 